\title{
ISOLASI DAN ANALISIS GEN HORMON PERTUMBUHAN LELE (Clarias gariepinus Burch.)
}

\author{
Ibnu Dwi Buwono"), Nono Carsono"*), dan Yuniar Mulyani") \\ *) Fakultas Perikanan dan Ilmu Kelautan, Universitas Padjajaran \\ Jl. Raya Bandung Sumedang km 21, Jatinangor 45363 \\ E-mail: ibnudw1@yahoo.com \\ ${ }^{* *)}$ Fakultas Pertanian, Universitas Padjajaran \\ Jl. Raya Bandung Sumedang km 21, Jatinangor 45363
}

(Naskah diterima: 31 Oktober 2011; Disetujui publikasi: 14 Agustus 2012)

\begin{abstract}
ABSTRAK
Isolasi gen hormon pertumbuhan lele dumbo (C. gariepinus) dari hipofisa ikan merupakan sumber DNA yang selanjutnya dapat digunakan sebagai cetakan untuk mengkopi gen tersebut menggunakan primer Amc-GH-F dan Amc-GH-R. Fragmen DNA lele dumbo hasil isolasi terdeteksi berdasar elektroforesis gel agarosa 1\%. Amplifikasi gen penyandi hormon pertumbuhan (Growth Hormone / GH) lele dumbo menggunakan primer Amc-GH-F (5'-GCAGAAATGGCTCGAGGTAAGG-3') dan Amc-GH-R (5'CAGGGTGCAGTTGGAATCC-3') dapat mengkopi sekuen gen GH lele dengan ukuran fragmen PCR sekitar 1.400 bp. Sementara amplikon gen GH American catfish (Rhamdia quelen) menggunakan primer Amc-GH-F dan Amc-GH-R sebesar 1.465 bp. Hasil analisis sekuensing gen penyandi $\mathrm{GH}$ menggunakan program BlastP dan Genetyx versi 7.0, menunjukkan bahwa sekuen gen penyandi GH lele dumbo memiliki homologi $80 \%$ dengan sekuen GH C. gariepinus pada bank gen (no. aksesi AF 416488.1), sehingga sebagian besar sekuen gen penyandi hormon pertumbuhan ikan tersebut dapat diamplifikasi secara in vitro.
\end{abstract}

KATA KUNCl: isolasi, analisis, gen hormon pertumbuhan, lele dumbo

ABSTRACT: Isolation and analysis of growth hormone gene African catfish (Clarias gariepinus Burch.). By: Ibnu Dwi Buwono, Nono Carsono, and Yuniar Mulyani

Isolation of African catfish growth hormone gene (C. gariepinus) from the pituitary of fish is a source of DNA that can then be used as a template for copying the gene using Amc-GH-F and Amc-GH-R primers. DNA fragments of the isolated from African catfish were detected by $1 \%$ agarose gel electrophoresis. Amplification of the gene encoding growth hormone African catfish using primer Amc-GH-F (5'GCAGAAATGGCTCGAGGTAAGG-3') and Amc-GH-R (5'-CAGGGTGCAGTTGGAATCC-3') can be used to copy GH gene sequences catfish the size of the test sample PCR fragments (African catfish) approximately 1,400 bp. While the GH gene amplicons American catfish (Rhamdia quelen) using Amc-GH-F and Amc-GH-R primers were 1,465 bp. The results of sequencing analysis of $G H$-coding genes using BlastP program and Genetyx version 7.0, indicating that the gene sequence coding for African catfish GH has $80 \%$ homology with sequences GH C. gariepinus in gen bank (accession no. AF 416488.1), so most of the growth hormone gene sequences coding for these fish can be amplified in vitro.

KEYWORDS: isolation, analysis, growth hormone gene, African catfish 


\section{PENDAHULUAN}

Hormon pertumbuhan (growth hormone) $\mathrm{GH})$ ikan merupakan hormon polipeptida yang disekresikan oleh hipofisis anterior. $\mathrm{GH}$ ini dapat memperbaiki kecepatan pertumbuhan individu ikan dengan meningkatkan biosintesis protein dan pengubahan lemak (lipid) (Feng et al., 2002).

Gen hormon pertumbuhan beberapa jenis ikan telah dapat dikloning dan disekuensing untuk keperluan konstruksi transgen 'all-fish' dalam vektor ekspresi ikan yang bersangkutan (Degani et al., 2006; Zhang et al., 2009). DNA genomik hormon pertumbuhan ikan dapat diisolasi dari kelenjar hipofisa ikan (Roberts et al., 2004; Alimuddin et al., 2007) dan mengandung coding sequence (cds) $\mathrm{GH}$ yang memiliki kesamaan (similarity) tinggi antara ikan yang masih sekerabat.

Gen GH Heteropneustes fossilis (lele India) memiliki ukuran 1.132 bp yang tersusun dari Open Reading Frame (ORF) atau cds berukuran 603 bp yang menyandikan 200 asam amino penyusun hormon tersebut (Anathy et al., 2001). Sementara itu, ukuran genom hormon pertumbuhan American catfish (Rhamdia quelen) sebesar $1.465 \mathrm{bp}$, yang mengandung ORF gen tersebut sebesar 603 bp (Vaz et al., 2010). Panjang fragmen ORF hormon pertumbuhan channel catfish (Ictalurus punctatus) dan blue catfish (Ictalurus furcatus) masingmasing adalah 689 bp dan 702 bp yang memiliki kemiripan tinggi pada sekuen ORF (Fei et al., 2010), di mana ORF merupakan sekuen penyandi protein hormon pertumbuhan ikan tersebut.

DNA hormon pertumbuhan dari I. punctatus (Anathy et al., 2001), Pangasius pangasius (Lemaire \& Panyim, 1993), P. gigas (Lemaire et al., 1994) dan $H$. fossilis telah dapat dikloning dalam Escherichia coli sebagai tahap awal untuk all fish gen transfer vector dalam upaya menghasilkan ikan auto transgenik.

Tujuan yang ingin dicapai dalam penelitian ini adalah mengisolasi gen hormon pertumbuhan lele dumbo (Clarias gariepinus) dan menganalisis sekuen gen penyandi hormon tersebut.

\section{BAHAN DAN METODE}

\section{Ikan Uji}

Ikan yang digunakan sebagai sampel uji adalah lele dumbo (Clarias gariepinus Burch.) diperoleh dari lokasi pembudidaya ikan lele di Sumedang berukuran sekitar $350-400 \mathrm{~g}$ per ekor. Hipofisa ikan digunakan sebagai sumber untuk ekstraksi DNA lele.

\section{Ekstraksi DNA Lele Dumbo}

Ekstraksi DNA lele dilakukan menggunakan kit High Pure DNA Tissue (Roche) mengacu pada protokol kit tersebut. Sampel berupa 10 mg jaringan hipofisa lele digerus lembut dengan pestle steril, kemudian dihomogenisasi dengan syringe plastik steril 5-10 kali, dan dilisiskan dengan penambahan $400 \mu \mathrm{L}$ lysis (binding buffer). Selanjutnya, lysate, disentrifugasi selama 2 menit pada kecepatan $14.000 \mathrm{rpm}$, dan ditambahkan $200 \mu \mathrm{L}$ etanol absolut yang dicampurkan menggunakan mikropipet. Campuran tersebut dipindahkan ke tabung koleksi $(2 \mathrm{~mL}$ ) yang telah diisi tabung filter (high pure filter tube) untuk menyaring lysate.

Tahap berikutnya melakukan sentrifugasi 30 detik pada kecepatan $14.000 \mathrm{rpm}$, dilanjutkan dengan pembuangan cairan dari tabung koleksi. Selanjutnya ditambahkan 500 $\mu \mathrm{L}$ wash buffer I ke dalam tabung filter, lalu disentrifugasi pada $11.000 \mathrm{rpm}$ selama 15 detik, dan cairan yang tertampung dalam tabung koleksi dibuang. Penambahan $500 \mu \mathrm{L}$ wash buffer II dilakukan kembali ke dalam tabung filter, kemudian disentrifugasi pada $14.000 \mathrm{rpm}$ selama 2 menit. Sentrifugasi dilakukan kembali selama 1 menit pada 14.000 rpm, lalu tabung filter diambil dari tabung koleksi dan ditempatkan ke dalam tabung eppendorf 1,5 mL steril.

Elusi DNA dilakukan dengan menambahkan $100 \mu \mathrm{L}$ elution buffer ke dalam tabung filter, kemudian disentrifugasi selama 1 menit pada $14.000 \mathrm{rpm}$, dan DNA sudah tertampung dalam tabung eppendorf 1.5 yang kemudian disimpan pada $-20^{\circ} \mathrm{C}$.

\section{Amplifikasi Sekuen Gen Penyandi GH Lele Dumbo}

Pengerjaan amplifikasi gen $\mathrm{GH}$ lele dumbo dilakukan untuk mendapatkan produk PCR berupa fragmen gen $\mathrm{GH}$ lele dumbo menggunakan primer Amc-GH-F dan Amc-GH-R serta fast start PCR master mix untuk keperluan amplifikasi tersebut. Penggunaan primer American catfish (Amc-GH-F : 5'GCAGAAATGGCTCGAGGTAAGG-3' dan AmcGH-R : 5'-CAGGGTGCAGTTGGAATCC-3') dapat dipakai untuk mengkopi sekuen gen $\mathrm{GH}$ lele 
dumbo (C. gariepinus) karena baik C. gariepinus dan American catfish (Rhamdia quelen) memiliki hubungan kekerabatan gen GH (Vaz et al., 2010). Ukuran amplikon GH R. Quelen dengan primer Amc-GH-F dan Amc-GH-R sebesar $1.465 \mathrm{bp}$.

Program amplifikasi gen $\mathrm{GH}$ lele dumbo dengan PCR, meliputi tahap pra denaturasi $94^{\circ} \mathrm{C}$ (3 menit); denaturasi $94^{\circ} \mathrm{C}$ (30 detik); annealing $55^{\circ} \mathrm{C}$ (30 detik); ekstensi $72^{\circ} \mathrm{C}$ (2 menit) dan ekstensi akhir $72^{\circ} \mathrm{C}$ (7 menit) dengan jumlah siklus penggandaan 35 .

Formulasi campuran reaksi PCR (volume total $50 \mu \mathrm{L}$ ), terdiri atas fast start $P C R$ master mix $25 \mu \mathrm{L}$; primer Amc-GH-F (25 pmol) $5 \mu \mathrm{L}$; primer Amc-GH-R (25 pmol) $5 \mu \mathrm{L}$; DNA (template) $5 \mu \mathrm{L}$ dan water PCR grade $10 \mu \mathrm{L}$. Sampel DNA yang sudah diamplifikasi kemudian disimpan pada suhu $-20^{\circ} \mathrm{C}$ semalam untuk pengerjaan elektroforesis.

\section{Elektroforesis}

Sampel DNA yang telah diamplifikasi, dianalisis dengan melakukan elektroforesis menggunakan gel agarosa secara submarine atau terendam seluruhnya. Sebanyak $10 \mu \mathrm{L}$ DNA hasil PCR dicampurkan dengan $3 \mu \mathrm{L}$ buffer pemuat (loading buffer), lalu dimasukkan ke dalam sumur-sumur yang dibentuk pada gel agarosa, satu sumur untuk 1 sampel DNA hasil amplifikasi. Konsentrasi gel agarosa $1 \%$, yang direndam dalam running buffer TBE 0,5X. Elektroforesis dijalankan pada voltase 75 volt selama 1,5 jam. Sebagai pembanding ukuran fragmen digunakan marker DNA ladder $1 \mathrm{~kb}$.

Gel agarosa hasil elektroforesis direndam dalam larutan etidium bromida (Et-Br) dengan konsentrasi $2 \mu \mathrm{g} / \mathrm{mL}$ selama 30 menit, selanjutnya gel agarosa dicuci dengan akuades selama 15 menit. Visualisasi pita DNA produk elektroforesis dilakukan di bawah lampu UV dengan panjang gelombang $\lambda=312 \mathrm{~nm}$ (UVIlluminator) dan difoto menggunakan kamera digital.

\section{Sekuensing GH Lele Dumbo}

Setelah diperoleh hasil amplifikasi sekuen $\mathrm{GH}$ lele dumbo dengan primer Amc-GH-F dan Amc-GH-R maka tahap selanjutnya dilakukan analisis sekuen DNA GH tersebut. Analisis sekuen $\mathrm{GH}$ lele tersebut menggunakan jasa service sekuensing PT Genetika Science Indonesia (Jakarta) untuk sampel produk PCR menggunakan primer Amc-GH-F dan Amc-GH-R.
Fragmen DNA hasil amplifikasi untuk sekuen gen $\mathrm{GH}$ lele dumbo ini perlu diverifikasi dengan menjajarkan (allignment) dengan sekuen gen $\mathrm{GH}$ Claria gariepinus (lele dumbo) yang terdapat pada bank gen untuk mengetahui kemiripan sekuen-sekuen tersebut, terutama coding sequence (sekuen penyandi) protein GH ikan (Punia et al., 2000). Fragmen DNA ini kemudian digunakan sebagai sampel untuk sekuensing.

Identifikasi urutan basa nukleotida dari fragmen tersebut menggunakan analisis kesejajaran lokal (local aligment) berdasarkan urutan nukleotida yang ada di GenBank melalui program BLAST (Basic Local Aligment Search Tools) yang diakses dari NCBI (National for Biotechnology Information) (http:// www.ncbi.nlm.nih.gov/BLAST/).

Sekuen nukleotida dan asam amino $\mathrm{GH}$ sampel uji hasil amplifikasi dibandingkan dengan data base dalam bank gen dengan program BlastP. Penjajaran (allignment) dan persentase kemiripan (similarity) asam amino dianalisis menggunakan program GENETYX versi 7.0 (Alimuddin et al., 2007).

\section{HASIL DAN BAHASAN}

\section{Isolasi DNA Lele Dumbo (C. gariepinus)}

Hasil isolasi DNA yang berasal dari hipofisa ikan lele dumbo berdasar uji elektroforesis gel agarosa 1\% disajikan pada Gambar 1 .

Hasil pembuktian keberadaan DNA hasil isolasi dari hipofisa ikan lele dumbo dengan elekroforesis gel agarosa $1 \%$ diperoleh fragmen DNA dari sampel uji isolat DNA lele dumbo (sumur ke-2, Gambar 1). Berdasarkan pedoman ukuran fragmen dari marker DNA ladder $1 \mathrm{~kb}$ (kisaran 0,2-10 kb), fragmen DNA lele dumbo berukuran lebih dari $10 \mathrm{~kb}$, dikarenakan mengandung banyak ekson-intron berbagai gen penyandi, sehingga ukuran fragmennya relatif panjang. Dengan demikian fragmen DNA dari sampel uji terdeteksi melalui elektroforesis gel agarosa 1\% (Roche, 2005).

\section{Amplifikasi Sekuen Growth Hormone (GH) Lele Dumbo}

Hasil optimasi PCR dengan menggunakan primer Amc-GH-F dan Amc-GH-R pada sampel uji (lele dumbo) disajikan dalam Gambar 2.

Fragmen DNA hasil amplifikasi yang tertera pada Gambar 2, yakni pada sumur ke-3, terpapar 2 fragmen dengan ukuran sekitar $1.400 \mathrm{bp}$ dan 


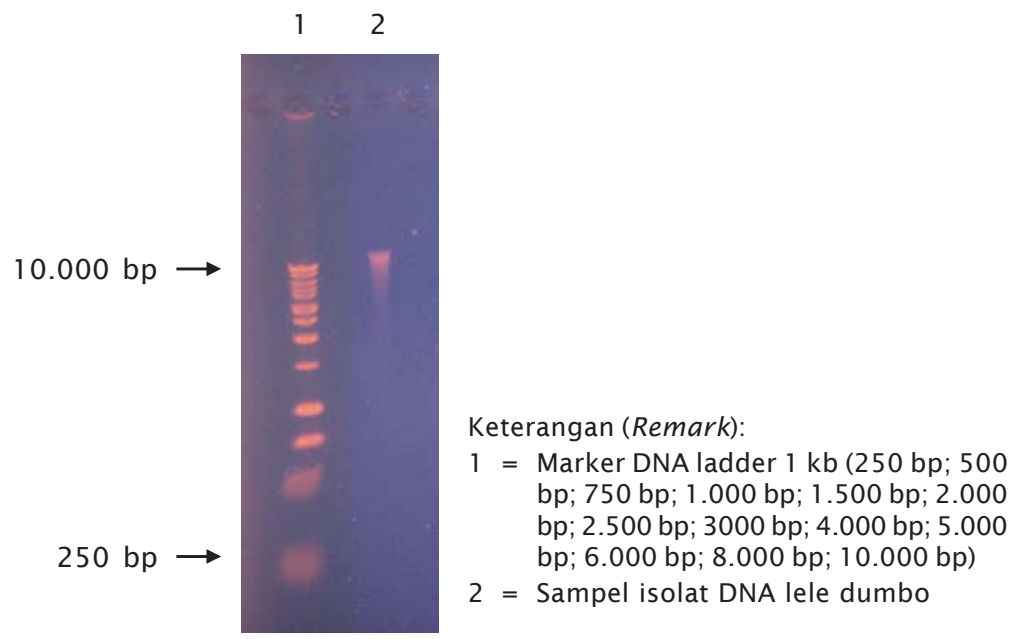

Gambar 1. Elektroforegram produk isolasi DNA lele dumbo

Figure 1. DNA isolation products electrophoregram in African catfish

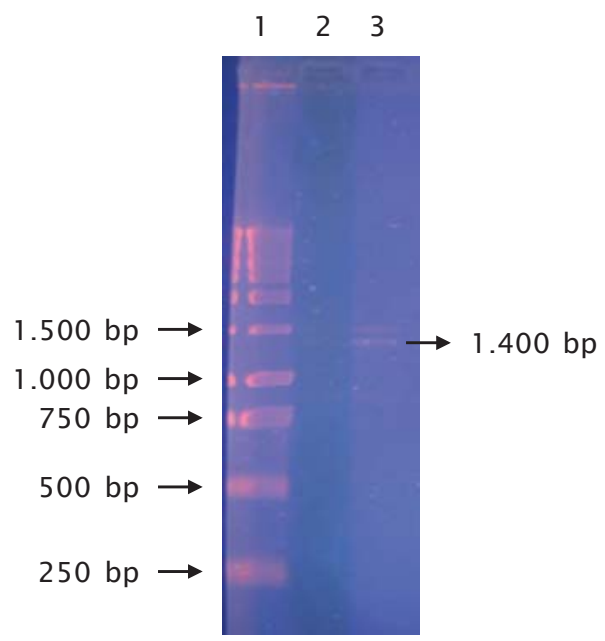

\author{
Keterangan (Remark): \\ Sumur 1 = Marker DNA ladder 1 kb (250 bp; 500 bp; \\ $750 \mathrm{bp} ; 1.000 \mathrm{bp} ; 1.500 \mathrm{bp} ; 2.000 \mathrm{bp}$; \\ $2.500 \mathrm{bp} ; 3.000 \mathrm{bp} ; 4.000 \mathrm{bp} ; 5.000 \mathrm{bp}$; \\ $6.000 \mathrm{bp} ; 8.000 \mathrm{bp} ; 10.000 \mathrm{bp})$ \\ Sumur 2 = Sampel produk PCR (primer Amc-GH-F/R \\ konsentrasi 10 pmol) \\ Sumur 3 = Sampel produk PCR (primer Amc-GH-F/R \\ konsentrasi 25 pmol)
}

Gambar 2. Elektroforegram fragmen gen $\mathrm{GH}$ lele dumbo

Figure 2. GH gene fragment electroforegram African catfish

$1.500 \mathrm{bp}$, dan didasarkan atas ukuran sekuen gen GH American catfish (Rhamdia quelen) sebesar $1.465 \mathrm{bp}$, fragmen DNA dari sampel uji (sekitar $1.400 \mathrm{bp}$ ) diduga merupakan kandidat kuat gen $\mathrm{GH}$ lele dumbo. Hal ini juga diperkuat dari hasil sekuensing gen $\mathrm{GH}$ Clarias gariepinus yang terdapat pada bank gen berukuran $1.456 \mathrm{bp}$, sehingga ukuran fragmen DNA sampel uji yang terpapar pada posisi $1.400 \mathrm{bp}$ tersebut merupakan gen penyandi $\mathrm{GH}$ lele dumbo. Lebih lanjut dikemukakan Feng et al. (2002), bahwa GH ikan sangat konser- vatif, di mana ikan-ikan dalam ordo atau famili yang sama menunjukkan homologi yang tinggi pada sekuen gen $\mathrm{GH}$ dan sekuen protein penyandi $\mathrm{GH}$.

Berpedoman hasil sekuensing gen $\mathrm{GH}$ pada bank gen, khususnya untuk $C$. gariepinus (lele dumbo) dengan nomor aksesi AF 416488.1 yang memiliki ukuran basa nukleotida $1.456 \mathrm{bp}$, maka diperlukan primer yang sesuai untuk gen $\mathrm{GH}$ ikan tersebut. Hasil penelitian Vaz et al. (2010) menunjukkan 
bahwa kekerabatan Clarias gariepinus dan Clarias batrachus berdasar sekuen gen $\mathrm{GH}$ nya memiliki homologi $99 \%$ dan antara kedua jenis Clarias tersebut dengan American catfish (Rhamdia quelen) memiliki kemiripan (similarity) berdasar sekuen GH sebesar $100 \%$. Dengan demikian dapat disimpulkan bahwa primer American catfish (Amc-GH-F dan Amc$\mathrm{GH}-\mathrm{R})$ dapat digunakan untuk mengkopi sekuen gen $\mathrm{GH}$ lele dumbo (Clarias gariepinus).

\section{Sekuen Growth Hormone (GH) Lele Dumbo}

Hasil sekuensing produk PCR dari sampel uji (menggunakan primer Amc-GH-R) dari PT. Genetika Science Indonesia (1 st BASE Molecular Biology Company-Malaysia) diperoleh ukuran panjang sekuen 713 nukleotida (nt) seperti Gambar 3. Sementara hasil sekuensing produk PCR dari sampel uji (menggunakan primer Amc-GH-F) tidak ditampilkan, oleh karena banyak nukleotida yang tidak terdeteksi.

Untuk mendapatkan kemiripan (similarity) antara sekuen gen yang terdapat pada bank gen dengan sekuen nukleotida gen sampel yang menyandikan protein hormon pertumbuhan, diperlukan program BLAST (Basic Local Alignment Search Tool) khususnya dengan program Blast-P secara online dan Genetyx versi 7.0 untuk mengetahui sekuen penyandi protein tersebut (Gambar 4).

Hasil penjajaran (alignment) dengan data sekuen $\mathrm{GH}$ yang ada di bank gen dengan program Blast-P, menunjukkan bahwa sekuen sampel uji memiliki kemiripan $80 \%$ dan $92 \%$ dengan sekuen protein $\mathrm{GH}$ spesies Clarias yang terdapat dalam data base bank gen (Tabel 1).

Berdasar sebaran nukleotida penyandi protein $\mathrm{GH}$ yang identik antara spesies $C$. gariepinus dalam bank gen (Tabel 1 ) dengan sampel uji (lele dumbo), kemiripannya relatif rendah, dikarenakan hasil sekuensing sampel uji parsial dari satu arah saja (reverse). Rendahnya kemiripan sekuen nukleotida GH lele dumbo (sampel uji) dengan GH spesies Clarias di atas, menyebabkan homologi sekuen asam amino residu antara lele dumbo dengan C. gariepinus dan C. batrachus relatif rendah (Gambar 5) (Alimuddin et al., 2007; Nugroho et al., 2008). Pada hasil sekuensing sampel uji (GH lele dumbo) di atas (Gambar 3), terkandung sekuen intron pada posisi nt. 713586 dari arah reverse berdasar analisis program Genetyx versi 7.0. Hal ini yang menyebabkan homologi sekuen $\mathrm{GH}$ lele dumbo dengan data GH spesies Clarias bank gen relatif rendah.

Hasil penjajaran sekuen asam amino $\mathrm{GH}$ lele dumbo (sampel uji) dengan data sekuen asam amino $\mathrm{GH}$ C. gariepinus pada bank gen, menunjukkan kemiripan $87 \%$ (Gambar 5), yang tidak jauh berbeda dengan hasil penjajaran sekuen nukleotida $\mathrm{GH}$ tersebut (Tabel 1). Sekuen-sekuen asam amino yang menunjukkan domain fungsional $\mathrm{CH}$ lele dumbo dengan GH Clarias gariepinus (no. aksesi AF416488.1) adalah empat residu sistein (notasi asam amino $\mathrm{C}$ ) yang merupakan karakteristik semua $\mathrm{GH}$ vertebrata, dan suatu residu ekstra sistein yang keberadaannya penting untuk aktivitas biologis dan integritas

GССTTTTCCCACCCCCCCCCCGAGGGGGGGGGGAAGGGGGAGGAAGGGGGGTCTTGAAGGTG GTAGTCACTGAACTACAGCCCTGGCTGCGTATTGAAAAATAAAGGGACGTCCGGGGTTGACTT TCTTCTTGACTTTTCTACTTATCAGTTTATGGACATAAAGCTAGACTTGTGGTGGTAACAGTC ACATTGTGCTTCATTTTTTAAATACGTAATGTACACCAATGTATTGCTTCTCTTCTTCTACAG TGTTGGTGCTGCTCTCTGTGGTGGTGGCGAGTCTGTTCTTTAATCAAGGCGCGACATTTGAGA CCCAGCGGCTCTTCAACAACGCGGTCATCCGTGTGCAACACCTTCACCAACTGGCTGCCAAGA TGATGGATGACTTTGTAAGCGTGCTGCAGACTGATGTAAGCATAGTTTACACCTACAGCAGGA AACGTGTTAGCTGTAAGCCTTAAGTTATGTGGATTCACGAGCTGAGTCTCGGGTTGTGTTGCA AATCTAAAAGGAAGAAGCTTTGGTACCTGAAGAACGCAAAGAGCTGAGCGAGATCTTCCGCCT GTCATTCTGCAACTCGGACTCTATCGAGGCTCCGGTAGTCGAGGACGAGACGCAGAAAGGCTC CGTGATTCACAGAGGTGGTGGCGTGAGAGTGTTAGGTATGGGAGAGTGGTCGGACGTGCGGTA GGACGTTGGGGGAGGATGTG

Gambar 3. Hasil sekuensing produk PCR GH lele dumbo arah reverse

Figure 3. The results of sequencing PCR products African catfish $\mathrm{GH}$ reverse direction 


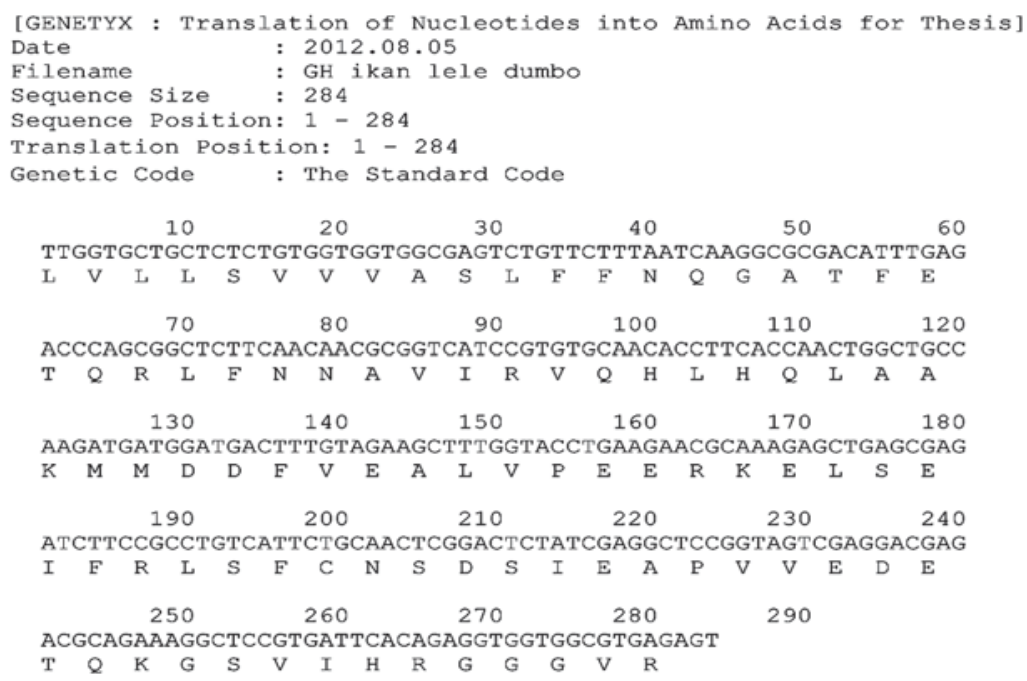

Gambar 4. Sekuen asam amino penyandi gen $\mathrm{GH}$ lele dumbo (hasil olah sekuen nukleotida produk PCR (program Genetyx versi 7.0)

Figure 4. Amino acid sequence of the gene encoding GH African catfish (the result of a nucleotide sequence of PCR product (Genetyx program version 7.0)

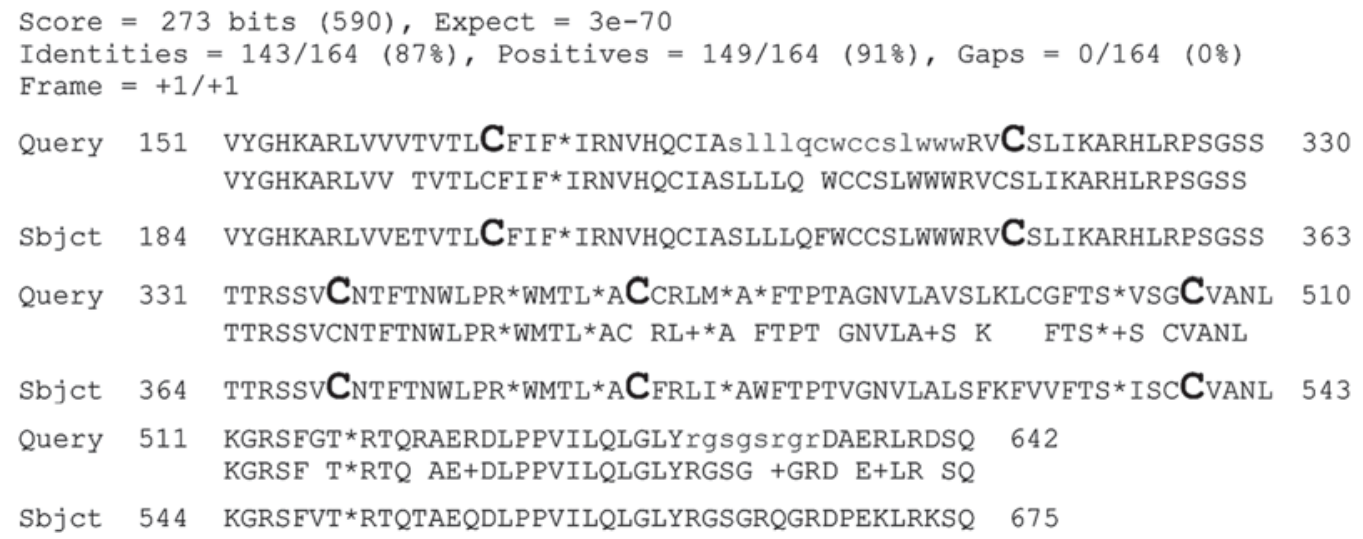

Gambar 5. Penjajaran sekuen asam amino GH sampel (lele dumbo) dengan sekuen asam amino GH Clarias gariepinus (no. aksesi AF416488.1) (program tBlastx). Huruf C yang ditebalkan merupakan asam amino Cysteine

Figure 5. Amino acid sequence alignment of $G H$ samples (African catfish) with $G H$ amino acid sequence of Clarias gariepinus (accession No. AF4 16488.1) (tBlastx program). Cletters which in bold is amino acid Cysteine

struktural hormon GH (Punia et al., 2000; Syaifudin, 2006). Lima residu sistein terdapat pada sekuen asam amino GH sampel uji (query) yang sejajar dengan sekuen asam amino tersebut pada GH bank gen (subject), menunjukkan bahwa sekuen produk PCR GH sampel merupakan nukleotida hormon pertumbuhan ikan lele dumbo.
Hasil-hasil penjajaran di atas, menunjukkan bahwa sebagian besar nukleotida hasil sekuensing sampel uji merupakan sekuen gen hormon pertumbuhan lele dumbo. Dengan demikian dapat disimpulkan bahwa produk PCR yang diperoleh dari sampel uji adalah kopi-kopi sekuen penyandi hormon pertumbuhan lele dumbo. 
Tabel 1. Homologi nukleotida GH lele dumbo dengan protein GH spesies Clarias yang ada dalam bank gen

Table 1. GH nucleotide homology with the African catfish with $\mathrm{GH}$ protein Clarias species which genes exist in the gene bank

\begin{tabular}{lcc}
\hline \multicolumn{1}{c}{$\begin{array}{c}\text { Spesies ikan } \\
\text { Fish species }\end{array}$} & $\begin{array}{c}\text { Nomor aksesi } \\
\text { Accession number }\end{array}$ & \% Homologi \\
\hline $\begin{array}{l}\text { Gen hormon pertumbuhan Clarias gariepinus } \\
\text { Clarias gariepinus growth hormone protein gene } \\
\begin{array}{l}\text { Gen hormon pertumbuhan Clarias batrachus } \\
\text { Clarias batrachus growth hormone protein gene }\end{array}\end{array}$ & AAL84166.1 & 80 \\
\hline
\end{tabular}

\section{KESIMPULAN}

Berdasarkan visualisasi elektroforesis produk PCR dari sampel cDNA lele dumbo menggunakan primer Amc-GH-F dan Amc-GH$\mathrm{R}$, amplikon yang diperoleh berukuran 1.400 bp, sebagian besar merupakan sekuen gen yang menyandi hormon pertumbuhan lele dumbo, oleh karena memiliki homologi $80 \%$ dengan sekuen gen $\mathrm{GH}$ Clarias gariepinus (no. aksesi AF416488.1), dan 92\% dengan C. batrachus (no. aksesi AF416486.2).

Hasil analisis sekuen $\mathrm{GH}$ lele dumbo menunjukkan keberhasilan amplifikasi gen penyandi hormon pertumbuhan lele tersebut secara in vitro menggunakan PCR.

\section{SARAN}

Diperlukan penggunaan primer spesifik, khususnya yang didesain dari ikan lele dumbo, untuk meningkatkan homologi gen penyandi hormon pertumbuhan ikan dan penggunaan ikan lele berukuran induk guna memperoleh DNA lele dalam konsentrasi relatif tinggi sehingga mempermudah proses sekuensing yang memberikan hasil sekuensing optimum.

\section{UCAPAN TERIMA KASIH}

Penulis mengucapkan terima kasih yang sebesarnya kepada Bapak Direktur Jenderal Pendidikan Tinggi, Direktorat Penelitian dan Pengabdian Kepada Masyarakat Kemendiknas dan Ketua Lembaga Penelitian dan Pengabdian Kepada Masyarakat UNPAD beserta jajarannya yang telah membiayai pelaksanaan penelitian ini dengan Dana DP2M Dikti Tahun Anggaran 2011 . Demikian pula diucapkan terima kasih kepada Tim Peneliti serta semua pihak yang telah membantu penelitian hingga selesai.

\section{DAFTAR ACUAN}

Alimuddin, Nugrahani, W., Aliah, R.S., Sumantadinata, K., Faizal, I., Carman, O., \& Yoshizaki, G. 2007. Isolasi dan karakterisasi promoter ß-actin dari ikan kerapu bebek (Cromileptes altivelis). J. Ris. Akuakultur, 2(2): 199-209.

Anathy, V., Venogupal, T., Koteswaran, R., Pandian, T.J., \& Mathavan, S. 2001. Cloning, sequencing and expression of cDNA encoding growth hormone from Indian catfish (Heteropneustes fossilis). J. Biosci., 26: 315-324.

Degani, G., Jackson, K., Yom-Din, S., \& Goldberg, D. 2006. cDNA cloning and mRNA expression of growth hormone in Belontiidae (Anabantoidei suborder). The Israeli Journal of Aquaculture-Bamidgeh, 58(2): 124136.

Fei, C., Lee, Y., Jiang, Y., Wang, S., Peatman, E., Abernathy, J., Liu, H., Liu, S., \& Liu, Z. 2010. Identification and characterization of fulllength cDNAs in Channel catfish (Ictalurus punctatus) and Blue catfish (Ictalurus furcatus). Plos One 5(7): el 1546.doi: 10.1371/journal.pone.0011546.

Feng, Qiang, jia, C., Liu, S., Jun, \& Yun, L. 2002. Molecular cloning and sequencing of growth hormone gene for black carp. Acta Laser Biology Sinica, 11 (6): 406-411.

Lemaire, C., Writ, S., \& Panyim, S. 1993. Pangasius pangasius growth hormone mRNA complete coding sequence (Gene Bank Accession Number M 63713).

Lemaire, C., Writ, S., \& Panyim, S. 1994. Giant catfish, Pangasionodon gigas growth hormone encoding cDNA cloning and sequencing by one sided polymerase chain reaction. Gene, 49: 271-276. 
Nugroho, E., Alimuddin, Kristanto, A.H., Carman, O., Megawati, N., \& Sumantadinata, K. 2008. Kloning cDNA hormon pertumbuhan dari ikan gurame (Osphronemus gouramy). J. Ris. Akuakultur, 3(2): 183-190.

Punia, P.S., Moriyama, S., Takahashi, A., \& Kawauchi, H. 2000. Molecular cloning of growth hormone complementary DNA in Barfin Flounder. Mar. Biotechnol., 2: 21-26.

Roberts, S., Barry, T., Malison, J., \& Goetz, F. 2004. Production of recombinantly derived growth hormone antibody and the characterization of growth hormone levels in yellow perch. Aquaculture, 232: 591-602.

Roche. Corporation. 2005. High Pure RNA Tissue Kit Protocols.
Syaifudin, M. 2006. Isolasi dan karakterisasi cDNA hormon pertumbuhan ikan kerapu bebek (Cromileptes altivelis). Tesis. Sekolah Pasca Sarjana IPB. Bogor, $65 \mathrm{hlm}$.

Vaz, B.Z., Cerqueira, G.M., Silva, J.C., Manzke, V.H.B., Moreira, C.G.A., \& Moreira, H.L.M. 2010. Sequence analysis of the growth hormone gene of the South American catfish Rhamdia quelen. Genetics and Molecular Research, 9(4): 2,184-2,190.

Zhang, Mao-qun, Cheng-zun, C., Yong-jun, G., Jing, G., \& Xiao-mei, W. 2009. Cloning and sequence analysis of full-length growth hormone cDNA from Clarias gariepinus. Acta Agricultural Boreali-Sinica, 24(6): 3237. 
Lampiran 1. Hasil sekuensing nukleotida sampel uji (lele dumbo) dari 1 st BASE (Malaysia)

Appendix 1. The results of nucleotide sequencing of the sample (African catfish) from 1 st BASE (Malaysia)

GCCTTTTCCCACCCCCCCCCCGAGGGGGGGGGGGAAGGGGGAGGAAGGGGGGTCTTG AAGGTGGTAGTCACTGAACTACAGCCCTGGCTGCGTATTGAAAAATAAAGGGACGTCC GGGGTTGACTTTCTTCTTGACTTTTCTACTTATCAGTTTATGGACATAAAGCTAGACTTGT GGTGGTAACAGTCACATTGTGCTTCATTTTTTAAATACGTAATGTACACCAATGTATTGC TTCTCTTCTTCTACAGTGTTGGTGCTGCTCTCTGTGGTGGTGGCGAGTCTGTTCTTTAAT CAAGGCGCGACATTTGAGACCCAGCGGCTCTTCAACAACGCGGTCATCCGTGTGCAAC ACCTTCACCAACTGGCTGCCAAGATGATGGATGACTTTGTAAGCGTGCTGCAGACTGAT GTAAGCATAGTTTACACCTACAGCAGGAAACGTGTTAGCTGTAAGCCTTAAGTTATGTG GATTCACGAGCTGAGTCTCGGGTTGTGTTGCAAATCTAAAAGGAAGAAGCTTTGGTACC TGAAGAACGCAAAGAGCTGAGCGAGATCTTCCGCCTGTCATTCTGCAACTCGGACTCT ATCGAGGCTCCGGTAGTCGAGGACGAGACGCAGAAAGGCTCCGTGATTCACAGAGGT GGTGGCGTGAGAGTGTTAGGTATGGGAGAGTGGTCGGACGTGCGGTAGGACGTTGGG GGAGGATGTG 